\title{
Glycemic Regulation and Cytotoxic Characteristics of the Ethyl Acetate Fraction from Passiflora cincinnata Mast Leaves
}

Charles dos S. Estevam 1,*, Clésio A. Lima ${ }^{1}$, Jymmys L. dos Santos ${ }^{1}$, Murilo Marchioro ${ }^{1}$, Brancilene S. Araújo ${ }^{1}$, Cristiane B. Corrêa ${ }^{2}$, Camila M. C. Santos ${ }^{2}$, Iara S. Santana ${ }^{3}$, Silvan S. de Araujo ${ }^{4}$

${ }^{1}$ Departamento de Fisiologia, Universidade Federal de Sergipe, Campus Universitário Prof. Aloísio de Campos, s/n, 49100-000, São Cristóvão-SE, Brazil. clesio.ufs@gmail.com (CAL); jymmys.lopes@gmail.com (JLS); murilomarchiolo@yahoo.com.br (MM); brancily@gmail.com (BSA)

2 Departamento de Morfologia, Universidade Federal de Sergipe, Campus Universitário Prof. Aloísio de Campos, s/n, 49100-000, São Cristóvão-SE, Brazil. crisbani@gmail.com (CBC); camilamenezes.c@gmail.com (CMCS)

3 Departamento de Enfermagem, Universidade Tiradentes, Campus Farolândia, Av. Murilo Dantas, n.300, 49032-490, Farolândia - Aracaju - SE, Brazil. Iara_samir@yahoo.com (ISS)

${ }^{4}$ Faculdade Mauricio de Nassau, Av. Augusto Franco, n. 2340, 49075-470, Siqueira Campos - Aracaju - SE, Brazil. silvan.ssa@gmail.com (SSA)

* Correspondence: cse.ufs@gmail.com; Tel: +51 (79) 3194-6647; Fax: +51 (79) 31946647

Abstract: Passiflora cincinnata Mast is a plant popularly used in traditional medicine in northeastern Brazil. The present study aimed to evaluate the anti-lipoperoxidative and anti- $\alpha$-amylase properties, and cytotoxicity of an extract and fraction of passion fruit leaves ( $P$. cincinnata Mast), as well as the antihyperglecemiant activity of the fraction rich in glycosylated flavonoids and showing low cytotoxicity in rats with a postprandial hyperglycaemia condition. The ethyl acetate fraction (F.ACT) of the P. cincinnata leaves presented the best anti-lipoperoxide properties with TBARs $81.49 \%, 95.48 \%$ and $75.62 \%$ lower than $\mathrm{AAPH}, \mathrm{FeSO}_{4}$ and $\mathrm{H}_{2} \mathrm{O}_{2}$ induced controls, respectively, at 200 $\mu \mathrm{g} . \mathrm{mL}^{-1}$. In addition, it presented an anti- $\alpha$-amylase potential, with a better ability to inhibit the $\alpha$-amylase enzyme in comparison to the acarbose control (IC $506.49 \pm 0.11$ and $12.01 \pm 0.4 \mu \mathrm{g} . \mathrm{mL}^{-1}$, respectively). The hydroalcoholic extract of $P$. cincinnata (ExEt) presented high content of total tannins, flavonoids and flavonols. However, F.ACT had the highest concentration of flavonoids among the fractions studied. HPLC analysis of this fraction revealed the presence of the flavonoids isovitexin, orientin and isoorientin. F.ACT showed low to no cytotoxicity below $150 \mu \mathrm{g} \cdot \mathrm{mL}^{-1}$. Regarding the post-prandial antihyperglycaemic activity of F.ACT, it was observed at 50 and 100 mg. $\mathrm{kg}^{-1}$.

Keywords: Passiflora cincinnata Mast; redox activity; cell cytotoxicity; $\alpha$-amylase inhibition; antihyperglycaemic

\section{Introduction}

Diabetes mellitus (DM) is a chronic metabolic disorder characterized by a high concentration of glucose in the blood (hyperglycemia) due to insulin deficiency and or 
resistance to it. Recurrent hyperglycemia can cause various damages to the body in the long term, particularly to the eyes, kidneys, nerves, heart and blood vessels [1]. It is estimated that there are over 250 million people worldwide with diabetes and that every 5 seconds a new case [2] emerges. As a result, [3] reported that the greatest challenge of Nutrition Science is to contain the rapid advance of morbidity and mortality from chronic noncommunicable diseases (NCDs) such as diabetes. It should be noted that epidemiological data show that it, along with hypertension, diabetes is the disease that kills most in Brazil [3].

The use of medicinal plants for the treatment, cure and prevention of pathologies is a habit that has accompanied humanity since its beginnings. According to estimates by the World Health Organization (WHO), $80 \%$ of the population in developing countries use medicinal plants for basic health care and $85 \%$ of traditional medicine involves the use of plant extracts [4]. [1] argue that medicinal plants are particularly interesting because they can not only be used as complementary and alternative remedies to prevent metabolic diseases, but are also a source of compounds with the potential to originate new antidiabetic drugs. They are capable of controlling glucose homeostasis in Diabetic subjects, meaning a lot for the patient's health.

Species of the genus Passiflora (passion fruit) are strongly used in folk medicine, mainly because of their recognized sedative and anxiolytic properties $[5,6,7,8,9]$. However, other properties are also attributed to passion fruit, whereas $P$. mollissiva is reported with a hypoglycemic effect [10], P. alata, P. edulis and P. encarnata are reported to have anti-inflammatory, anti-inflammatory, anti-spasmodic, antimicrobial, antidiabetic, antioxidant and hypotensive effects $[11,10,12,13]$. Passiflora cincinnata Mast is a native species of semi-arid regions, widely used in folk medicine, mainly in northeastern Brazil, in the states of Alagoas, Bahia, Pernambuco and Sergipe, which is popularly known as maracujá-do-mato [14]. Its leaves are commonly used for their soothing, hypotensive, hypoglycemic and anti-inflammatory activities [15]. However, its phytochemical, pharmacological and toxicity characteristics are not well established. [16], when quantifying the content of some phenolic compounds in the pulp of $P$. cincinnata, found a moderate content of $\beta$-carotene and traces of anthocyanins. Whereas, [15] observed the presence of flabenamic tannins, flavonoids, catechins, 
steroids, alkaloids and saponinic heterosides in the ethanolic extract of the leaves this plant, using qualitative techniques.

Although the Passiflora genus is widely used and accepted in traditional medicine because of its pharmacological properties, the phytochemical constituents responsible for these properties are not yet elucidated, although [17] suggested that some of the medicinal properties of Passiflora are associated with the presence of C-glycosylated flavonoids. [11] reported that the major constituents in Passiflora leaves are flavonoids derived from apigenin and luteolin (vitexin, isovitexin, orientin, isoorientin). However, the levels of these flavonoids differ between species [18].

It is important to note that studies determining toxicity and cytotoxicity in Passiflora species are rare [19], and dosages and effective concentrations for glycemic index control are not known. In order to justify the medicinal properties and popular use of $P$. cincinnata in glucose homeostasis, the present study aimed to evaluate the antilipoperoxidative and anti- $\alpha$-amylase effects and cytotoxicity of the extract and leaf fractions of passion fruit ( $P$. cincinnata Mast), as well as the antihyperglecemiant activity of the flavonoid rich fraction with low cytotoxicity in rats in postprandial hyperglycemia.

\section{Experimental}

\subsection{Materials}

Vitexin, isoorientin, rutin, tannic acid, $\alpha$-amylase from porcine pancreatic (EC 3.2.1.1, type VI) and 3,5-dinitrosalicyclic acid were purchased from Sigma-Aldrich Corporation (St. Louis, MO, USA). Metformin hydrochloride was purchased from Vitapan Indústria Farmacêutica Ltda (Anápolis, GO, Brazil). Acarbose was purchased from Bayer S.A (São Paulo, Brazil). Glucose was purchased from Vetec ${ }^{\circledR}$ AG (Rio de Janeiro, Brazil). All reagents were of analytical grade. Salts and solvents were purchased from Merck AG (Darmstadt, Germany).

\subsection{Plant Material}

P. cincinnata Mast leaves were collected in the morning of March 2008, in the city of Moita Bonita (latitude $10^{\circ} 34^{\prime} 00.4^{\prime \prime} \mathrm{S}$ and longitude $37^{\circ} 20^{\prime} 51.8^{\prime \prime} \mathrm{W}$ ), in the state of Sergipe, Brazil, and taken to the Federal University of Sergipe UFS). The voucher of the species was deposited in the Herbarium of the institution, with the identification 
number ASE 11.112. The identification was made by $\mathrm{Dr}^{\mathrm{a}}$. Ana Paula do Nascimento Silva of the Department of Biology.

\subsection{Preparation of Extract and Fractions of $P$. cincinnata}

After drying in an oven (MARCONI, model 037/18) with air circulation and constant temperature of $40{ }^{\circ} \mathrm{C}, P$. cincinnata leaves were reduced to powder using a knife mill, and then subjected to extraction with $95 \%$ ethanol by thorough maceration during 5 days. After this period, the material was filtered and concentrated in a rotary evaporator under reduced pressure (BUCHI, model 461) at $55 \pm 2{ }^{\circ} \mathrm{C}$ to give the hydroalcoholic extract (ExEt).

Part of the ExEt (50 g) was diluted in a methanol/water solution (2:3) and subjected to liquid-liquid extraction with hexane, dichloromethane, chloroform, ethyl acetate and methanol. Chlorophyll removal and cleaning of the extract and fractions were performed by filtration in active charcoal and silica gel chromatographic column under the flow of the corresponding solvents. At the end, ExEt, F.MET and F.ACT samples were stored in freezer at $-20^{\circ} \mathrm{C}$ for further studies.

\subsection{Chromatographic Profile by HPLC-UV-DAD}

A Shimadzu high performance liquid chromatographic system (Prominencemodel, Kyoto, Japan) was used consisting of a model DGU-20A3 vacuum cleaner, LC-6A high pressure pumps and photodiode arrangement (DAD-marking) detection system coupled with Interface CBM 20A. Data collection was performed using LC Solution software. Analyzes were performed using a Phenomenex LUNAs analytical C18 column (250 x $4.6 \mathrm{~mm}$ i.d., $5 \mu \mathrm{m}$ particle diameter, Torrance, CA, USA), while the component separations were performed through a reverse phase elution gradient. To that end, $20 \mu \mathrm{L}$ of ExEt, F.MET and F.ACT (1 mg.mL $\left.{ }^{-1}\right)$, previously filtered using a membrane with $0.20 \mu \mathrm{m}$ in diameter, were injected into the mobile phase consisting of $2 \%$ formic acid (A) and acetonitrile (B) [53]. The established flux was $0.8 \mathrm{~mL} \cdot \mathrm{min}^{-1}$ under 0-10 min gradient, $15 \% \mathrm{~B} ; 11-50 \mathrm{~min} 30 \% \mathrm{~B}$, and $51-60 \min 15 \% \mathrm{~B}$. The UV spectra were obtained at the range of $240-400 \mathrm{~nm}$.

\subsection{Quantification of Phenolic Constituents}

\subsubsection{Total Tannins (TT)}


The total tannins content was determined according to [54] with minor modifications. Briefly, $1 \mathrm{~mL}$ of the ExEt, F.MET and F.ACT at $100 \mu \mathrm{g} \cdot \mathrm{mL}^{-1}$ was mixed with $1.6 \mathrm{~mL}$ of Follin-ciocalteu and $1 \mathrm{~mL} 1 \mathrm{mmol} \cdot \mathrm{L}^{-1} \mathrm{Na}_{2} \mathrm{CO}_{3}$. After $40 \mathrm{~min}$, the absorption of each sample was measured at $760 \mathrm{~nm}$. The results were expressed as milligrams of tannic acid equivalents per grams of dry weight (TA mg . $\mathrm{g}^{-1} \mathrm{DW}$ ). All analyses were performed in triplicate.

\subsubsection{Total Flavonoids (FvT)}

The total flavonoids content was determined according to [55] with minor modifications. Briefly, $1 \mathrm{~mL}$ of the ExEt, F.MET and F.ACT at $100 \mu \mathrm{g} \cdot \mathrm{mL}^{-1}$ was mixed with $1 \mathrm{~mL}$ of $2 \%$ aluminum trichloride. After $40 \mathrm{~min}$, the absorption of each sample was measured at $427 \mathrm{~nm}$. The results were expressed as milligrams of rutin equivalents per grams of dry weight (RU mg.g-1 DW). All analyzes were performed in triplicate.

\subsubsection{Total Flavonols (FnT)}

The total flavonois content was determined according to [55] with minor modifications. Briefly, $1 \mathrm{~mL}$ of the ExEt, F.MET and F.ACT at $100 \mu \mathrm{g} \cdot \mathrm{mL}^{-1}$ was mixed with $1 \mathrm{~mL}$ of $2 \%$ aluminum trichloride and $2 \mathrm{~mL}$ of $0.5 \%$ sodium acetate. After 150 min, the absorption of each sample was measured at $440 \mathrm{~nm}$. The results were expressed as milligrams of rutin equivalents per grams of dry weight (RU mg.g-1 DW). All analyzes were performed in triplicate.

\subsection{Inhibitory Activity of Lipoperoxidation in Vitro}

The degree of lipid peroxidation prevented by the hydroethanol extract and fractions was monitored by measuring the production of thiobarbituric acid-reactive substances (TBARS) [56, 57, 58]. Briefly, $100 \mu \mathrm{L}$ oleic acid (2.51 mol.L-1) was mixed with freshly prepared solutions of ExEt, F.MET, F.ACT and positive controls $(200 \mu \mathrm{g}$ $\mathrm{mL}^{-1}$ ). Lipid peroxidation was induced by adding either $2^{\prime}$-azobis(2-amidinopropane) dihydrochloride (AAPH, 0.17 mol.L $\left.{ }^{-1}, 0.1 \mathrm{~mL}\right)$, ferrous sulfate $\left(\mathrm{FeSO}_{4}, 0.17\right.$ mol.L ${ }^{-1}$, $0.1 \mathrm{~mL})$ or hydrogen peroxide $\left(\mathrm{H}_{2} \mathrm{O}_{2}, 0.4 \mathrm{~mol} . \mathrm{L}^{-1}, 0.1 \mathrm{~mL}\right)$. Trolox was used as positive control, while the negative control was the vehicle (PBS). The mixture was incubated for $30 \mathrm{~min}$ at $37^{\circ} \mathrm{C}$. Upon cooling, samples $(0.5 \mathrm{~mL})$ were mixed with trichloroacetic acid (TCA, 15\%, $0.5 \mathrm{~mL}$ ) and centrifuged at $1200 \times \mathrm{g}$ for $10 \mathrm{~min}$. Supernatant was taken $(0.5 \mathrm{~mL})$, mixed with thiobarbituric acid $(0.67 \%, 0.5 \mathrm{~mL})$, incubated for $30 \mathrm{~min}$ at 95 
${ }^{\circ} \mathrm{C}$, and the formation of TBARS was measured by reading the supernatant absorbance at $532 \mathrm{~nm}$ after cooling. The molar extinguish coefficient used was $1.54 \times 10^{5} \mathrm{M}^{-1} . \mathrm{cm}^{-1}$ and the results were expressed as nmol of malondialdehyde equivalent per gram of sample (Eq MDA nmol.g-1 ${ }^{-1}$.

\subsection{Determination of $\alpha$-Amylase Inhibitory Activity}

The $\alpha$-amylase inhibition assay was performed using a literature method with modifications [59]. Porcine pancreatic $\alpha$-amylase was dissolved in 20 mmol. $\mathrm{L}^{-1}$ sodium phosphate buffer ( $\mathrm{pH}$ 6.9, containing $6.7 \mathrm{mmol} . \mathrm{L}^{-1}$ sodium chloride) to provide a 40 unit.mL $\mathrm{mL}^{-1}$ solution. A total of $20 \mu \mathrm{L}$ of ExEt, F.MET, F.ACT $\left(1,10\right.$ and $\left.20 \mu \mathrm{g} \cdot \mathrm{mL}^{-1}\right)$ and $50 \mu \mathrm{L}$ of the enzyme were preincubated at $25^{\circ} \mathrm{C}$ for $30 \mathrm{~min}$. The samples were dissolved in methanol. After preincubation, $250 \mu \mathrm{L}$ of the preincubated solution was mixed with $500 \mu \mathrm{L}$ of $1 \%$ starch solution in $20 \mathrm{mmol}^{-1}$ sodium phosphate buffer $(\mathrm{pH}$ 6.9, containing $6.7 \mathrm{mmol} . \mathrm{L}^{-1}$ sodium chloride). The reaction mixtures were then incubated at $40{ }^{\circ} \mathrm{C}$ for $20 \mathrm{~min}$. The reaction was stopped by adding $500 \mu \mathrm{L}$ of 3,5-dinitrosalicylic acid (DNS) color reagent solution (96 mmol.L $\mathrm{L}^{-1}$ of DNS, 5.31 mol.L ${ }^{-1}$ sodium potassium tartrate in $2 \mathrm{~mol} . \mathrm{L}^{-1} \mathrm{NaOH}$ ). After that, the test tubes were incubated in a boiling water bath for $5 \mathrm{~min}$ and later cooled to room temperature. The reaction was diluted by adding $4.5 \mathrm{~mL}$ of distilled water. $\alpha$-Amylase activity was determined by measuring the release of maltose from starch at $540 \mathrm{~nm}$. The amount of maltose formed was determined using a standard curve. Control incubations represented $100 \%$ of enzyme activity and were conducted in a similar way by replacing extracts with buffer. For blank incubation to measure the absorbance produced by the extract, the enzyme solution was replaced with buffer. The inhibitory activity was determined by comparing the enzyme activity in the absence and presence of the evaluated inhibitor. Acarbose was used as a positive control.

The enzyme inhibitory activity was calculated using the following formula:

$$
\% \text { Inhibition }=[(\mathrm{C}-\mathrm{A}) / \mathrm{C}] \times 100
$$

Where $\mathrm{C}$ represents the absorbance of the enzyme activity and contains enzyme and substrate; and A represents the absorbance of the test and contains enzyme, plant extract, and substrate. Any increase in absorbance due to the spontaneous hydrolysis of substrate or unspecific enzyme inhibition was corrected by subtracting the absorbances 
between the samples and the blank incubation. The $\mathrm{IC}_{50}$ values were estimated by nonlinear regression analysis [1].

\subsection{Cytotoxicity Assessment by MTT}

L929 fibroblast lineage was seeded in 96-well culture plates $\left(2 \times 10^{4}\right.$ cells per well) and cultured in DMEM medium $\left[\mathrm{NaHCO}_{3}\left(1.2\right.\right.$ g.L $\left.{ }^{-1}\right)$, ampicillin $\left(0.025\right.$ g.L $\left.{ }^{-1}\right)$, streptomycin $\left(0.1\right.$ g. $\left.\left.\mathrm{L}^{-1}\right)\right]$ supplemented with $10 \%$ fetal bovine serum. Fibroblasts were submitted to different treatments with ExEt, F.MET and F.ACT (10, 20, 50, 100 and $150 \mu \mathrm{g} . \mathrm{mL}^{-1}$ ) or vehicle (dimethylsulfoxide - DMSO) during $24 \mathrm{~h}$ at $37^{\circ} \mathrm{C}$ and $5 \% \mathrm{CO}_{2}$ atmosphere. Cell viability was assessed by the colorimetric method using Methylthiazolyl-tetrazolium (MTT) according to ISO 10993-5/2009. MTT is a yellow dye, which is reduced by mitochondrial and cytoplasmic enzymes to a blue compound called formazan that is insoluble in aqueous solution. The reduction of MTT tetrazolium salt, mainly by the mitochondrial succinate dehydrogenase enzyme [60], is widely used in cell survival and proliferation evaluation trials, since only viable cells reduce MTT to formazan, which can be spectroscopically quantified [61, 62]. A solution of MTT $(0.025 \mathrm{~g}$ in $50 \mathrm{ml}$ of PBS) was placed in contact with the cells, which were then incubated at $37{ }^{\circ} \mathrm{C}$ for $3 \mathrm{~h}$. After MTT removal, DMSO was placed for $10 \mathrm{~min}$ to solubilize the crystals of the tetrazolic salt, and then the optical density (OD) reading was performed using an automated plate reader at $570 \mathrm{~nm}$. The assays were performed in quadruplicate and then normalized according to the following equation:

$$
\% \text { Viabilidade cellular }=\frac{\text { Abs (treated cells })- \text { Abs (blank) }}{\text { Abs (positive control) }- \text { Abs (blank) }}
$$

\subsection{Animals}

The male Wistar rats (180-200 g) used in this study were bred in the animal facility of the Laboratory of Biochemistry and Natural Product Chemistry, in the Department of Physiology of the Federal University of Sergipe, and housed in an air-conditioned room $\left(22 \pm 1^{\circ} \mathrm{C}\right)$ with controlled lighting on a 12:12 h light/dark cycle (lights on from 06:00 to 18:00 h). The animals were fed pelleted food (Nuvital, Nuvilab CR1, Curitiba, PR, Brazil), while tap water was available ad libitum. Fasted animals were deprived of food for at least $16 \mathrm{~h}$, but allowed free access to water. All the animals were monitored and maintained in accordance with the ethical recommendations of the Brazilian Veterinary Medicine Council (CMV) and the Brazilian College of Animal Experimentation 
(COBEA). The study was approved by the Ethic Committee of the Federal University of Sergipe under the protocol number 58/09 - CEPA/UFS.

\subsection{Oral Glucose Tolerance Curve (OGTC)}

The analysis of F.ACT anti-diabetic activity was performed by the oral glucose tolerance test (OGTT) in normoglycemic rats according to the protocol described by $[63,64]$ with modifications. Briefly, rats were fasted and fed with water at $8 \mathrm{~h}$ and randomly divided into 4 groups consisting of 6 animals each: Group I, hyperglycemic mice receiving glucose at $3 \mathrm{~g} \cdot \mathrm{kg}^{-1}$; Group II and III, hyperglycemic rats receiving F.ACT at 50 and $100 \mathrm{mg} \cdot \mathrm{kg}^{-1}$, respectively; and Group IV, hyperglycemic mice receiving metformin at $500 \mathrm{mg} \cdot \mathrm{kg}^{-1}$. Blood glucose was measured before the mice received the treatment (time zero). Rats were treated with F.ACT and loaded with glucose after $30 \mathrm{~min}$ and after measuring the blood glucose at 30, 60, 90 and $120 \mathrm{~min}$. All treatments were administered by oral gavage.

Blood glucose levels were obtained through reagent tapes (ACCU-CHECK Advantage II, Roche) coupled to a portable digital glycosimeter from blood samples collected from the tail.

\subsection{Data and Statistical Analysis}

Data were expressed as means \pm S.E.M. After observing the homogeneity of the data through the Shapiro-Wilk test, the significant differences between the dependent variables $(\mathrm{p}<0.05)$ were evaluated through ANOVA with Bonferroni's, KruskalWallis's and Dunn's post hoc tests when appropriate, using the GraphPad Prism 7.0 statistical program (San Diego, California, EUA).

\section{Results and Discussion}

\subsection{Phytochemical Characterization}

In our study, spectrophotometric analyzes of ExET and fractions of $P$. cincinnata Mast showed a high content of phenolic compounds in the form of tannins, flavonoids and flavonols in relation to other species of the genus [11, 20, 21, 22, 23], strengthening the evidence that flavonoids are the major components in several species of the genus Passiflora (table 1). To corroborate with these observations, it was previously shown that ExEt had a high amount of phenolic compounds and flavonoids using the HPLC analyzis [24]. 
Table 1. Content of total tannins (TT), total flavonoids (FvT) and total flavonols (FnT) of the extract and fractions of $P$. cincinnata Mast leaves.

\begin{tabular}{cccc}
\hline Samples & TT $^{*}$ & FvT $^{* *}$ & FnT** $^{* *}$ \\
\hline ExEt - PAS & $9.16 \pm 0.11^{\mathrm{a}}$ & $177.06 \pm 2.09^{\mathrm{a}}$ & $6.38 \pm 0.28^{\mathrm{a}}$ \\
F. MET - PAS & $4.72 \pm 0.22^{\mathrm{b}}$ & $42.73 \pm 4.23^{\mathrm{b}}$ & $3.62 \pm 0.10^{\mathrm{b}}$ \\
F. ACT - PAS & $5.96 \pm 0.25^{\mathrm{c}}$ & $74.06 \pm 9.53^{\mathrm{c}}$ & $5.79 \pm 0.27^{\mathrm{c}}$
\end{tabular}

*Data are mean \pm S.E.M. values, expressed as tannic acid equivalents $\mathrm{mg.g}^{-1}$ of dry weight $(\mathrm{n}=6)$; **Data are mean \pm S.E.M. values, expressed as rutin equivalents $\mathrm{mg} . \mathrm{g}^{-1}$ of dry weight $(\mathrm{n}=6)$. Values in the columns with different letters indicate significant differences $(\mathrm{p}<0.05)$.

[23] Reported that most of the biological activities of Passiflora species, such as antioxidant, anticancer, anti-inflammatory, cardioprotective, antithrombotic, hypoglycemic and antihyperglycemic effects, as well as their role in preventing cellular lipoperoxidation and improving the endothelial function $[25,26]$, are attributed to the presence of phenolic and flavonoid compounds. On the other hand, [17] emphasize that these activities are associated more precisely to the C-glycosylated flavonoids. When analyzing F.MET and F.ACT fractions, the presence of 5 and 8 characteristic peaks of glycosylated flavonoids, respectively, were observed when comparing the UV absorption spectra of the chromatographic peaks of the fractions studied with flavonoid pattern spectra described by $[27,28,29,30,31]$, suggesting to be the flavonoids vitexin (peak 4 - F.MET) and isovitexin, orientin and isoorientin (peaks 2, 5 and 7 - F.ACT, respectively) (figure 1). Corroborating our findings, [21, 22] demonstrated that the highest prevalence of flavonoids found in Passiflora species is C-glycosylated type derived from apiginine and luteolin. 

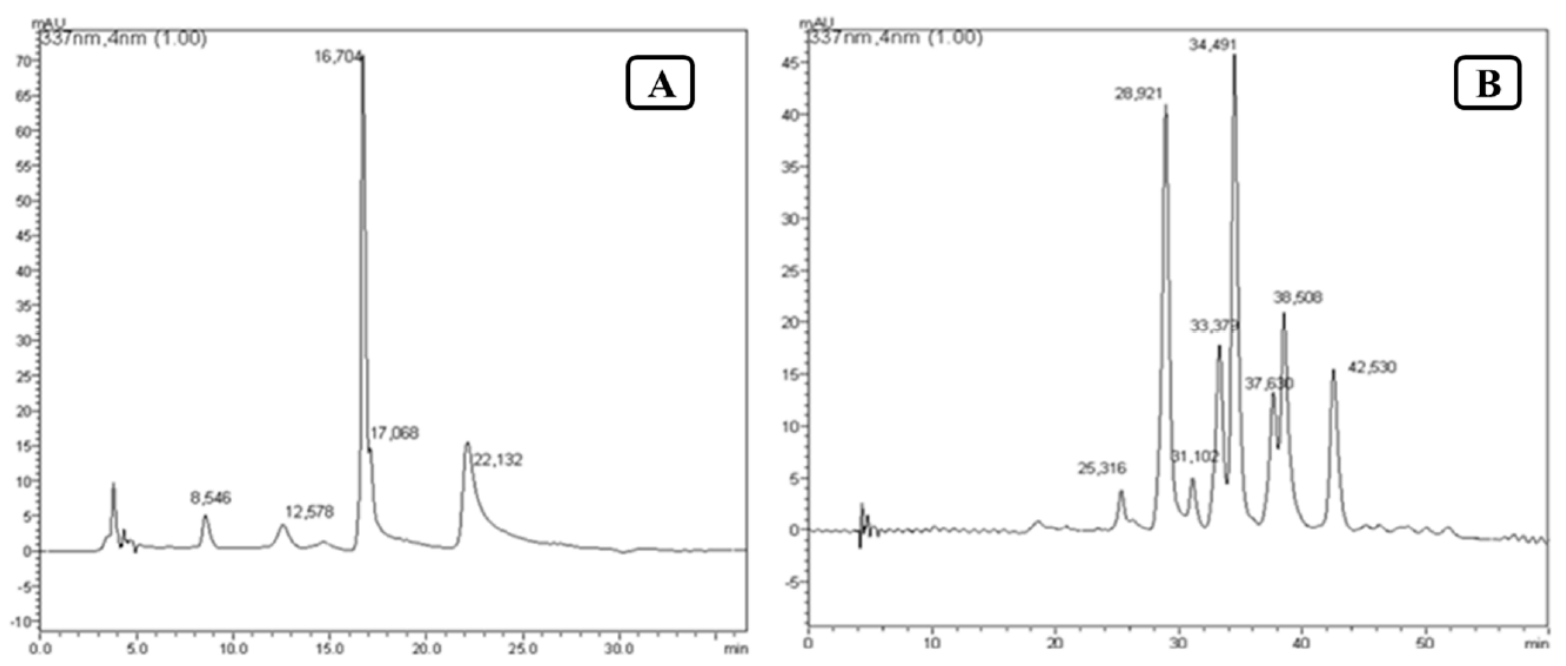

Figure 1. HPLC chromatogram from the methanol (A) and ethyl acetate (B) fractions of the leaves of Passiflora cincinnata Mast. Mobile phase consisted of 2\% formic acid (a) and acetonitrile (b); 0 - 10 minutes $15 \%$ (b), 11 - 16 minutes $30 \%$ (b), 17-25 minutes $45 \%$ (b). An aliquot of $20 \mu \mathrm{L}$ was injected in the chromatograph and detection was done at $337 \mathrm{~nm}$.

\subsection{Redox Property}

When evaluating the redox capacity of the extract and fractions of $P$. cincinnata to prevent lipoperoxidation through the estimation of inhibition of thiobarbituric acid reactive species (TBARs) formation induced by three free radical chemical generators, a significant $(p<0.05)$ increase of TBAR levels in the induced control groups over untreated controls (unpublished data) was observed. In addition, it was found that F.ACT-PAS presented better redox activity, with TBARs $81.49 \%, 95.48 \%$ and $75.62 \%$ lower than observed for AAPH, $\mathrm{FeSO}_{4}$ and $\mathrm{H}_{2} \mathrm{O}_{2}$ induced controls, respectively, at 200 mg. $\mathrm{mL}^{-1}$ (figure 2). The redox response of F.ACT-PAS was similar to the synthetic antioxidant Trolox regarding the lipoperoxidation inhibition when induced by AAPH and $\mathrm{FeSO}_{4}$. 
๑

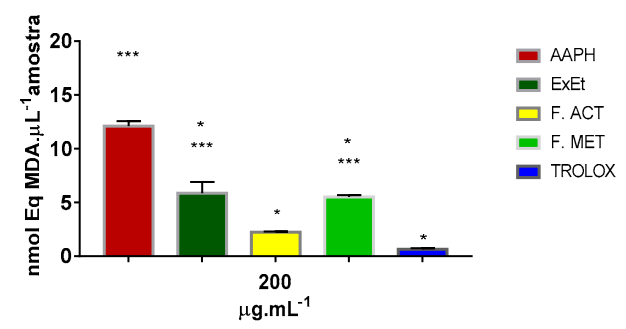

○

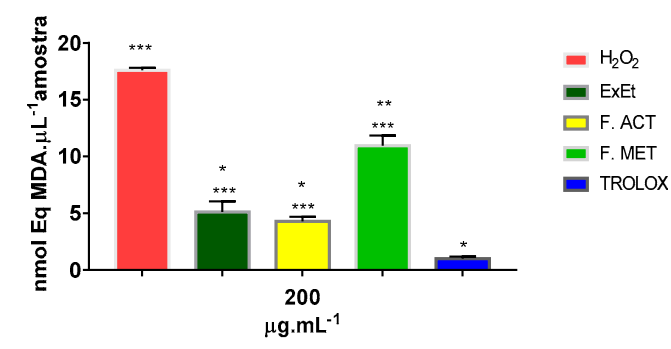

回

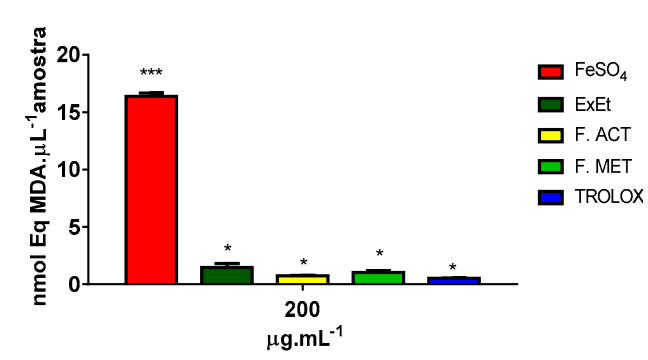

Figure 2. Effect of the hydroethanol extract (ExEt) and methanol (F.MET) and ethyl acetate (F.ACT) fractions of Passiflora cincinnata Mast on the formation of TBARs induced by AAPH (A), FeSO4 (B) and $\mathrm{H} 2 \mathrm{O} 2(\mathbf{C})$. Values expressed as Eq MDA nmol.mL-1. *Significant differences $(p<0.0001)$ compared to inducer. ${ }^{* *}$ Significant differences $(\mathrm{p}<0.0002)$ compared to inducer. ${ }^{* *}$ Significant differences $(p<0.05)$ compared to conrrol Trolox.

A substantial amount of studies shows that diabetes is a unique condition in reducing enzymatic and non-enzymatic antioxidant defense systems, favoring reactions of lipoperoxidation and cellular damage $[31,33,34]$. In parallel, clinical and laboratory studies report that some species of the genus Passiflora are able to improve the antioxidant system of the organism and reduce the levels of lipoperoxidation in diabetically induced experimental animals, as well as diabetic subjects [31, 35, 36, 37]. For [38, 39], these protective effects are attributed to flavonoids that in biological systems transfer electrons to free radicals, chelate metals, activate antioxidant enzymes and inhibit oxidases, thus preventing diseases associated with oxidative stress.

Considering the studies that indicate the presence of flavonoids in Passiflora extracts and their relationship with pharmacological properties, it was shown that different total flavonoid contents can be found for the different Passiflora species [11, 40, 41, 42, 43]. However, [44, 45, 46] stated that the higher the content of these compounds, the greater the redox activity and the greater the ability of the plant product to prevent the organism from injury associated with free radicals. Data corroborating these findings are present in the present study. 


\section{3. $\alpha$-Amylase Inhibitory Activity of $P$. cincinnata Fractions}

Diabetes is characterized by a rapid increase in blood glucose levels due to the hydrolysis of the starch by pancreatic $\alpha$-amylase. Several $\alpha$-amylase inhibitors, including acarbose, voglibose and miglitol, are clinically used in the treatment of diabetes, but their prices are high and clinical side effects are also observed. As a result, [46] suggested the use of natural glycoside inhibitors in the control of postprandial glycemia. [47] reported that due to the presence of phenols and flavonoids, several medicinal plants are still the most promising sources for the discovery of $\alpha$-amylase inhibitor, receiving considerable attention from the pharmaceutical industry. The fact is that these medicines are quite relevant for those people who have just been diagnosed with type 2 diabetes and who have blood glucose levels only slightly above the level considered serious for diabetes.

When the ability of ExEt, F.MET and F.ACT to inhibit the $\alpha$-amylase enzyme in vitro was evaluated, ExEt showed no inhibitory activity at the concentrations tested. On the other hand, F.MET and F.ACT presented significant $(\mathrm{p}<0.05)$ inhibitory potential for $\alpha$-amylase, whereas F.ACT showed its best activity in relation to the other samples at $20 \mu \mathrm{g} \cdot \mathrm{mL}^{-1}$, with $89.16 \%$ of inhibition (table 2) and the lowest $\mathrm{IC}_{50}$, which was half of the value observed for control acarbose. A study conducted by [47] demonstrated that ethanol and aqueous extracts from other Passiflora species have $\alpha$-amylase inhibitory activity at a dose-dependent concentration. In that study, the highest concentration of the ethanol and aqueous root extracts $\left(100 \mu \mathrm{g} \cdot \mathrm{mL}^{-1}\right)$ showed inhibitions of $80.3 \%$ and $83.3 \%$, respectively, which were lower than observed for $P$. cincinnata F.ACT in the present study. This shows a better potential for inhibiting $\alpha$-amylase than other species of the genus studied.

Table 2. Inhibition of $\alpha$-amylase by fractions of $P$. cincinnata.

\begin{tabular}{cccc}
\hline Samples & Concentration $\left(\boldsymbol{\mu g . \mathbf { m L } ^ { - 1 } )}\right.$ & Inhibition $(\%)$ & IC $_{\mathbf{5 0}}\left(\boldsymbol{\mu g} . \mathbf{m L}^{\mathbf{- 1}}\right)$ \\
\hline \multirow{2}{*}{ F.MET } & 1 & $13.74 \pm 2.04^{\mathrm{a}}$ & \\
& 10 & $32.82 \pm 0.26^{\mathrm{b}}$ & \\
& 20 & $38.17 \pm 1.26^{\mathrm{c}} \pm 1.29^{\mathrm{a}}$ \\
& 1 & $6.02 \pm 0.75^{\mathrm{a}}$ & \\
F.ACT & 10 & $60.24 \pm 4.11^{\mathrm{d}}$ & \\
& 20 & $89.16 \pm 3.36^{\mathrm{e}}$ & \\
& 1 & $24.14 \pm 3.73^{\mathrm{f}}$ & \\
\hline
\end{tabular}




\begin{tabular}{cccc}
\hline Acarbose & 10 & $51.72 \pm 5.38^{\mathrm{g}}$ & $12.01 \pm 0.40^{\mathrm{c}}$ \\
& 20 & $76.44 \pm 4.14^{\mathrm{h}}$ & \\
\hline
\end{tabular}

Results are represented by mean \pm S.E.M. All assays were carried out in three replicates. The values in the column with the same letters do not indicate significant differences $(\mathrm{p}<0.05)$.

\subsection{MTT Cytotoxicity Assessment}

Usually several plant-derived compounds exert serious cytotoxic or mutagenic effects when applied to animal tissues and cells [48]. Because of this, it is important to evaluate the cytotoxicity of plant extracts and fractions commonly used in traditional medicine to give security to the population that uses them frequently. In this sense, the cytotoxicity of $P$. cincinnata extract and fractions against the L929 fibroblast lineage was observed at concentrations higher than $100 \mu \mathrm{g} \cdot \mathrm{mL}^{-1}$ for ExEt and $150 \mu \mathrm{g} \cdot \mathrm{mL}^{-1}$ for F.ACT, while F.MET was not cytotoxic at any of the concentrations evaluated (figure 3). Results for the minimum efficient concentration for viable cells at 50\% ( $\mathrm{EC}_{50}$ ), showed that ExEt is significantly $(\mathrm{p}<0.05)$ more cytotoxic than F.ACT, with values of of $54.41 \pm 4.17$ and $74.37 \pm 13.92 \mu \mathrm{g} \cdot \mathrm{mL}^{-1}$, respectively.

[19] evaluated the acute toxicity of the lyophilized aqueous extract of $P$. alata, which had a low toxicity; however, they affirmed that toxicity studies of Passiflora species are rare. As far as our knowledge is concerned, only one study has evaluated the cytotoxicity of $P$. cincinnata Mast [49], showing high cytotoxicity for the hydroalcoholic extract of leaves at $1000 \mu \mathrm{g} \cdot \mathrm{mL}^{-1}$, which caused a mortality of $68.63 \%$ of NCTC929 fibroblasts. On the other hand, the hydroalcoholic extracts of stem, bark and seeds in concentrations between 200 and $500 \mu \mathrm{g} \cdot \mathrm{mL}^{-1}$ had low cytotoxicity. In that study, samples were considered to have no cytotoxicity when the concentrations were $125 \mu \mathrm{g} \cdot \mathrm{mL}^{-1}$ or higher. 

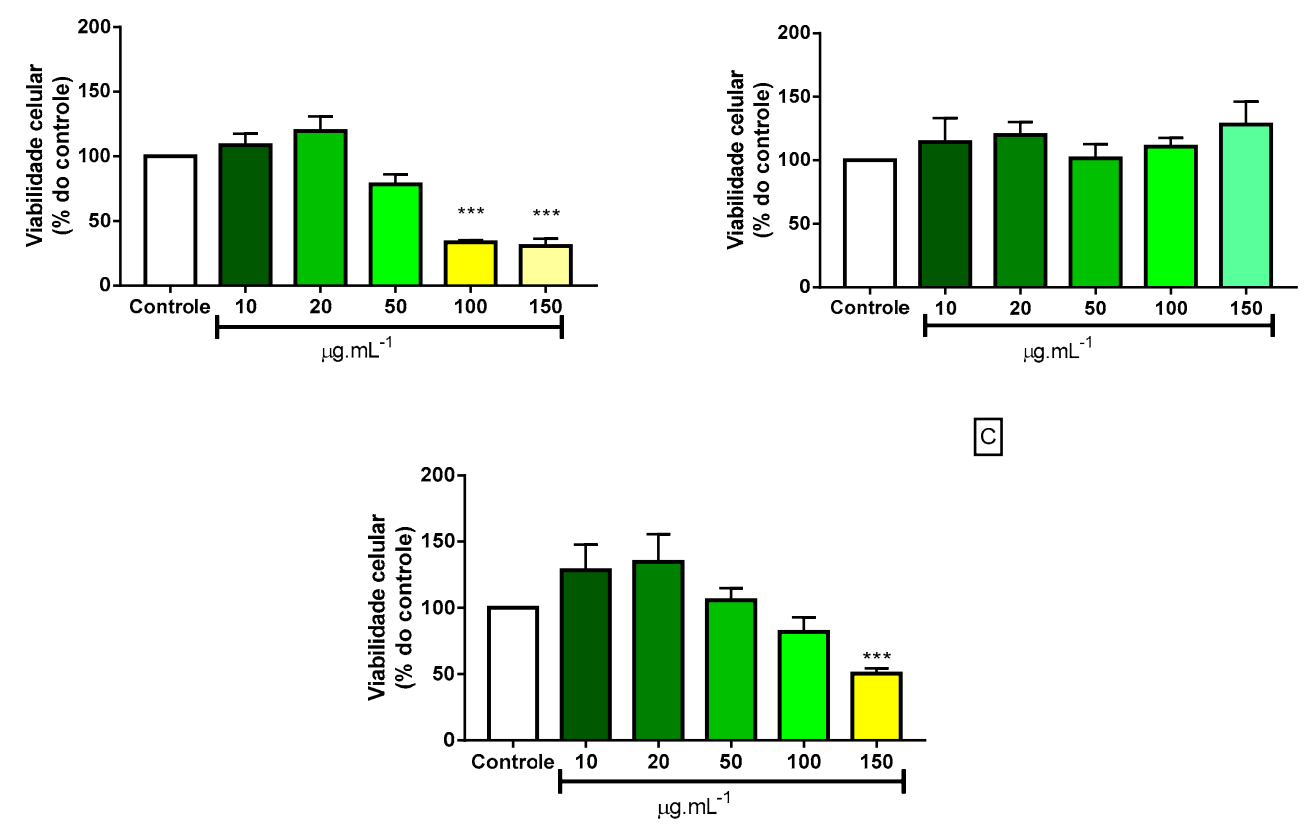

Figure 3. Effects of ExEt (A), F.MET-PAS (B) and F.ACT-PAS (C) from P. cincinnata on the L929 fibroblast cell lineage. L929 cells were treated with samples for 24 hours at $37^{\circ} \mathrm{C}$ in humid atmosphere and with $5 \% \mathrm{CO} 2$ and had cell viability determined by the MTT assay. Each bar represents the mean \pm SEM for metabolically active cells compared to the control normalized in $100 \%$ and were obtained from 2 independent experiments, each performed in quadruplicate. ${ }^{* * *}(\mathrm{p}<0.001)$ relative to the control (untreated cells).

\subsection{Effect of the Ethyl Acetate Fraction of $P$. cincinnata on the Oral Glucose}

\section{Tolerance Curve}

To verify the effects of drugs on glucose metabolism, the TOTG method is used because it is low cost and fast way to perform. In normoglycemic rats, post-pradial glycemia increases after a glucose overload, while its normalization to basal levels occur after about $2 \mathrm{~h}$, characterizing a normal function of glucose metabolism. As the F.ACT fraction of $P$. cincinnata showed positive redox activity in preventing liperoxidation, excellent potential to inhibit glycosidases ( $\alpha$-amylase) and low cellular cytotoxicity, it was evaluated as a natural product candidate to maintain glycemic homeostasis in rats normoglycemic after glucose overload.

Thus, as expected for the TOTG, after 30 min of glucose overload, blood glucose levels significantly $(\mathrm{p}<0.05)$ increased when compared with time zero in the hyperglycemic control group. However, when the positive control Metformin (500 $\mathrm{mg} . \mathrm{kg}^{-1}$ ), an oral hypoglycemic standard of the biguanide class, was used a decrease in 
blood glucose at all evaluation periods (30 to $120 \mathrm{~min}$ ) was observed compared to the hyperglycemic group (table 3). Metformin mechanism of action involves the inhibition of glucose uptake by the gastrointestinal tract, reduction of hepatic glucose production and increase of the sensitivity of peripheral tissues to insulin, enabling alterations of the glucose metabolism by inhibiting postprandial glucose elevation in approximately 25 to $30 \%$ [50], as verified in the present study.

Table 3. Acute effect of ethyl acetate fraction (F.ACT) of P. cincinnata leaves on blood glucose levels (mg.dL-1) in oral glucose tolerance curve.

\begin{tabular}{|c|c|c|c|c|}
\hline \multirow{2}{*}{$\begin{array}{l}\text { Time } \\
\text { (min) }\end{array}$} & \multirow{2}{*}{$\begin{array}{c}\text { Group I Hyper } \\
(3 \mathrm{~g} / \mathrm{kg})\end{array}$} & \multicolumn{2}{|c|}{ Hyper + F.ACT } & \multirow{2}{*}{$\begin{array}{c}\text { Group IV } \\
\text { Hyper + Metformina } \\
\left(500 \mathrm{mg} . \mathrm{kg}^{-1}\right)\end{array}$} \\
\hline & & $\begin{array}{c}\text { Group II } \\
50 \text { mg.kg-1 }\end{array}$ & $\begin{array}{c}\text { Group III } \\
100 \text { mg.kg-1 }\end{array}$ & \\
\hline $\mathbf{0}$ & $98.00 \pm 6.95^{\#}$ & $85.50 \pm 6.48$ & $87.10 \pm 17.05$ & $88.60 \pm 8.37$ \\
\hline 30 & $177.60 \pm 15.54$ & $146.30 \pm 19.62^{*}$ & $122.60 \pm 29.13 * * *$ & $127.30 \pm 21.22 * * *$ \\
\hline 60 & $156.80 \pm 11.29$ & $137.10 \pm 7.99$ & $148.60 \pm 39.45$ & $102.00 \pm 10.72 * *$ \\
\hline 90 & $142.80 \pm 6.11$ & $131.60 \pm 7.01$ & $143.90 \pm 26.73$ & $110.10 \pm 11.91 * * *$ \\
\hline 120 & $127.00 \pm 8.88$ & $127.40 \pm 8.99$ & $121.40 \pm 5.25$ & $111.70 \pm 4.99 * *$ \\
\hline
\end{tabular}

Values are expressed as mean \pm S.E.M. $\mathrm{N}=8$ in triplicate for each treatment. Statistically significant differences by comparison with Group I. \#Statistically significant at $(\mathrm{p}<0.001)$ in relation to $30 \mathrm{~min} ; * \mathrm{p}<0.05 ; * * \mathrm{p}<0.01 ; * * * \mathrm{p}$ $<0.001$.

With a similar response to the positive control, F.ACT of $P$. cincinnata leaves was effective in reducing postprandial glycemia after 30 minutes for both doses tested (50 and $100 \mathrm{mg} \cdot \mathrm{kg}^{-1}$ ) compared to the hyperglycemic control. However, the dose of 100 $\mathrm{mg} . \mathrm{kg}^{-1}$ produced the best antihyperglycemic profile after $30 \mathrm{~min}$, with a reduction of $30.96 \%$ of the hyperglicemy compared to control. After $2 \mathrm{~h}$ of treatment, the glycemic levels of the groups treated with F.ACT was improved in a similar manner to the hyperglycemic control. [36] showed that $200 \mathrm{mg} \cdot \mathrm{kg}^{-1}$ of Passiflora incarnata methanol extract generated a significant improvement in oral glucose tolerance in normal rats after acute ingestion of $3 \mathrm{~g} . \mathrm{kg}^{-1}$ of glucose.

We believe that such effects can be explained in part by a decrease in the rate of intestinal glucose uptake achieved by an inhibitory action of glycolytic enzymes [51] generated by the biological action of flavonoids and phenolic compounds present in the F.ACT sample [36]. [52] demonstrated that purified phenolic compounds from P. edules (purple passion fruit) seeds extract at doses of 10 and $50 \mathrm{mg} \cdot \mathrm{kg}-1$ are effective in reducing hyperglycemia in mice. 


\section{Conclusions}

The results of the present study indicate that the ethyl acetate fraction of (F.ACT) of $P$. cincinnata leaves is rich in glycosylated flavonoids and phenolic derivatives and is able to inhibit the $\alpha$-amylase glycolytic enzyme, improving postprandial glucose homeostasis in normoglycemic rats without significant cytotoxicity. In addition, leaf hydroalcoholic extract and methanol fraction were sources of tannins, flavonoids and flavonols, besides showing anti-lipoperoxidative activity against lipid oxidation induced by $\mathrm{AAPH}, \mathrm{FeSO}_{4}$ and $\mathrm{H}_{2} \mathrm{O}_{2}$. Further studies are needed to identify the molecule(s) responsible for the postprandial antihyperglycemic activity and exact mechanism of action on glucose homeostasis.

Conflict of Interest: The authors declare no conflict of interest.

\section{References}

[1] KAPPEL, V.D.; PEREIRA, D.F.; CAZAROLlI, L.H.; GUESSER, S.M.; DA SILVA, C.H.B.; SCHENKEL, E.P.; REGINATTO, F.H.; SILVA, F.R.M.B. Short and long-term effects of Baccharis articulata on glucose homeostasis. Molecules. 2012, 17, 6754-6768.

[2] SILVA, M.; DE LIMA, W.G.; SILVA, M.E.; PEDROSA, M.L. Effect of streptozotocin on the glycemic and lipid profiles and oxidative stress in hamsters. Arq. Bras. Endocrinol. Metab. 2011, 55, 46-53.

[3] HENRIQUES, G.S.; HELM, C.V.; SIMEONE, M.L.F. Comparação da glicemia de ratos feitos diabéticos por estreptozotocina e de ratos normais a partir da ingestão de dietas experimentais ricas em fibra alimentar de diferentes fontes. Rev. Med. Res. 2013, 15, 258-271.

[4] WHO. Guidelines for training traditional health practitioners in primary health care. (2006).Disponível em http//www.who.int/medicines/areas/traditional/en/index.html. Acesso em: 10 de dez. de 2016.

[5] AKHONDZADEH, S.; NAGHAVI, H.R.; VAZIRIAN, M.; SHAYEGANPOUR, A.; RASHIDI, H.; KHANI, M. Passion flower in the treatment of generalized anxiety: a pilot double-blind randomized controlled trial with oxazepam. J. Clin. Pharm. 2001, 26, 363-367.

[6] DE PARIS, F.; PETRY, R.D.; REGINATTO, F.H.; GOSMANN, G.; QUEVEDO, J.; SAlGUEIRO, J.B.; KAPCZINSKI, F.; ORTEGA, G.G.; SCHENKEL, E.P. Pharmacochemical study of aqueous extracts in Passiflora alata Dryander and Passiflora edulis Sims. Acta Farm. Bona. 2002, 21, 5-8.

[7] CARLINI, E.A. Plants and the central nervous system. Pharmacol. Biochem. Behav. 2003, 75, 501-512.

[8] DHAWAN, K.; DHAWAN, S.; SHARMA, A. Passiflora: a review update. J. Ethnopharmacol. 2004, 94, 1-23. 
[9] ERNST E. Herbal remedies for anxiety - a systematic review of controlled clinical trials. Phytomedicine. 2006, 13, 205-208.

[10] EDWIN, E.; SHEEJA, E.; DHANABAL, S.P.; SURESH, B. Antihyperglycemic activity of Passiflora mollissima Bailey. Indian J. Pharma. Sci. 2007, 69, 570-571.

[11] MUllER, S.D.; VASCONCELOS, S.B.; COELHO, M.; BIAVETTI, M.M. LC and UV determinations of flavonoids from Passiflora alata medicinal extracts and leaves. J. Pharma. Biomed. Anal. 2005, 37, 399-403.

[12] MONTANHER, A.B.; ZUCOLOTTO, S.M.; SCHENKEL, E.P.; FRODE, T.S. Evidence of anti-inflammatory effects of Passiflora edulis in an inflammation model. $\boldsymbol{J}$.

Ethnopharmacol. 2007, 109, 281-288.

[13] MULlER, V.; CHÁVEZ, J.H.; REGINATTO, F.H.; ZUCOLOTTO, S.M.; NIERO, R.; NAVARRO, D.; YUNES, R.A.; SCHENKEL, E.P.; BARARDI, C.R.; ZANETTI, C.R.; SIMÕES, C.M.; Evaluation of antiviral activity of South American plant extracts against herpes simplex virus type 1 and rabies vírus. Phytother. Res. 2007, 21, 970-974.

[14] OLIVEIRA, J.C.; RUGGIERO, C. Espécies de maracujá com potencial agronômico, $1^{\text {st }}$ ed.; Embrapa Cerrados: Brasilia, Brazil, 2005, pp. 143-158.

[15] LIMA, C.A. Atividade redox-protetora da Passiflora Cincinnata mast sobre o estresse oxidativo Induzido pelo exercício físico. MSc. in Health Science, Federal University of Sergipe, São Cristovão, 03/02/2011. In https://bdtd.ufs.br/handle/tede/1016

[16] LESSA, A.O. Determinação do teor de compostos fitoquímicos e estudo do potencial para processamento da polpa de frutos de maracujás da espécie silvestres (Passiflora setácea DC, Passiflora cincinnata MAST). MSc. in Food Engineering, State University of the Southwest of Bahia, Itapetinga, 08/08/2011. In http://www.uesb.br/ppgengalimentos/dissertacoes/2011/DETERMINA\%C3\%87\%C3\% 83O $\% 20$ DO $\% 20$ TEOR $\% 20$ DE $\% 20$ COMPOSTOS $\% 20$ FITOQU\%C3\%8DMICOS\%20 E\%20ESTUDO\%20DO\%20POTENCIAL\%20PARA\%20PROCESSAMENTO\%20DA \%20POLPA\%20DE\%20FRUTOS\%20DE\%20MARACUJ\%C3\%81\%20DAS.pdf

[17] SENA, L.M.; ZUCOLOTTO, S.M.; REGINATTO, F.H.; SCHENKEL, E.P.; DE LIMA, T.C. Neuropharmacological activity of the pericarp of Passiflora edulis flavicarpa Degener: putative involvement of C-glycosylflavonoids. Exp. Biol. Med. 2009, 234, 967-975.

[18] Mendez, A.S.L.; Simionato, N.O.; Valduga, A.T.; Reginatto, F.H. Caracterização de preparações extrativas obtidas de Passiflora alata Curtis. Rev. Ciênc. Farm. Bás. Apl. 2011, 32, 105-11.

[19] GOSMANN, G. Composição química e aspectos farmacológicos de espécies de Passiflora L. (Passifloracea). Rev. Bras. Biocien. 2011, 9, 88-99.

[20] CHABARIBERI, R.A.O.; POZZI, A.C.S.; ZERAIK, M.L.; YARIWAKE, J.H. Determinação espectrométrica dos flavonóides das folhas de Maytenus (Celastraceae) e de Passiflora (Passifloraceae) e comparação com método CLAE-UV. Braz. J. Pharmacogn. 2009, 19, 860-864. 
[21] MADOGLIO, F.A. Investigação fitoquímica das partes aéreas de Passiflora alata curtis. MSc in Pharmacy, Federal University of Santa Catarina, Florianopólis, 24/03/2011. In https://repositorio.ufsc.br/handle/123456789/95525

[22] STRASSER, M.; NORIEGA, P.; LÖBENBERG, R.; BOU-CHACRA, N.; BACCHI, E.M. Antiulcerogenic potential activity of free and nanoencapsulated Passiflora serratodigitata L. extracts. BioMed. Res. Int. 2014, 2014, 7p.

[23] SIMIRGIOTIS, M.J.; SCHMEDA-HIRSCHMANN, G.; BÓRQUEZ, J.; KENNELLY, E.J. The Passiflora tripartita (banana passion) fruit: a source of bioactive flavonoid C-glycosides isolated by HSCCC and characterized by HPLC-DADESI/MS/MS. Molecules. 2013, 18, 1672-1692.

[24] WOSCH, L.; DOS SANTOS, K.C.; IMIG, D.C.; SANTOS, C.A.M. Comparative study of Passiflora taxa leaves: II. A chromatographic profile. Rev. Bras. Farmacogn. 2017, 27, 40-49.

[25] SCALBERT, A.; MANACH, C.; MORAND, C.; REMESY, C. Dietary polyphenols and the prevention of diseases. Crit. Rev. Food Sci. Nut. 2005, 45, $287-$ 306.

[26] JUNG, M.; PARK, M.; LEE, H.C.; KANG, Y.; KANG, E.S.; KIM, S.K. Antidiabetic agents from medicinal plants. Curr. Med. Chem. 2006, 13, 1203-1218.

[27] HARBORNE, J.B.; MABRY, T.J.; MABRY, H. The Flavonoids, $1^{\text {st }}$ ed.; Chapman and Hall Ltd.: London, Great Britain, 1975, 1129p.

[28] HARBORNE, J.B. (1998). Phytochemical methods: a guide to modern techniques of plant analysis, $3^{\text {rd }}$ ed.; Chapman and Hall Ltd.: London, Great Britain, 1998, 302p.

[29] SINGH, A.P.; WILSON, T.; KALK, A.J.; CHEONG, J.; VORSA, N. Isolation of specific cranberry flavonoids for biological activity assesment. Food Chem. 2009, 116, 963-968.

[30] MORRONE, M.S.; ASSIS, A.M.; ROCHA, R.F.; GASPAROTTO, J.; GAZOLA, A.C.; COSTA, G.M.; ZUCOLOTTO, S.M.; CASTELLANOS, L.H.; RAMOS, F.A.; SCHENKEL, E.P.; REGINATTO, F.H.; GELAIN, D.P.; MOREIRA, J.C. Passiflora manicata (Juss.) aqueous leaf extract protects against reactive oxygen species and protein glycation in vitro and ex vivo models. Food Chem. Toxicol. 2013, 60, 45-51.

[31] ROCHA, F.D.; TEIXEIRA, V.L.; PEREIRA, R.C.; KAPLAN, M.A.C. Diabetes mellitus and oxidative stress: natural products as target of new therapeutics types. Rev. Bras. Farm. 2006, 87, 49-54.

[32] REIS, J.S.; VELOSO, C.A.; MATTOS, R.T.; PURISH, S.; MACHADO, J.A.N. Estresse oxidativo: revisão da sinalização metabólica no diabetes tipo 1. Arq. Bras. Endocrinol. Metab. 2008, 52, 1096-1105.

[33] SILVA, J.K.; CAZARIN, C.B.B., COLOMEU, T.C.; BATISTA, A.G., MELETTI, L.M.M.; PASCHOAL, J.A.R.; BOGUSZ JÚNIOR, S.; FURLAN, M.F.; REYES, F.G.R.; AUGUSTO, F.; MARÓSTICA JÚNIOR, M.R.; ZOLLNER R.L. Antioxidant activity of aqueous extract of passion fruit (Passiflora edulis) leaves: in vitro and in vivo study. Food Res. Int. 2013, 53, 882-890. 
[34] PEREIRA, C.A.M.; VILEGAS, J.H.Y. Constituintes químicos e farmacologia do gênero Passiflora com ênfase na $P$. alata Dryander., $P$. edulis Sims e $P$. incarnata L. Rev. Bras. Plantas Med. 2000, 3, 1-12.

[35] GUPTA, R.K.; KUMAR, D.; Chaudhary, A.K.; Maithani, M.; Singh, R. Antidiabetic activity of Passiflora incarnata Linn. in streptozotocin-induced diabetes in mice. J. Ethnopharmacol. 2012, 139, 801- 806.

[36] CORRÊA, R.C.G.; PERALTA R.M.; HAMINIUK, C.W.I.; MACIEL, G.M.; BRACHT, A.; FERREIRA, I.C.F.R. The past decade findings related with nutritional composition, bioactive molecules and biotechnological applications of Passiflora spp. (passion fruit). Trends Food Sci. Technol. 2016, 58, 79-95.

[37] ALVES, C.Q.; DAVID, J.M.; DAVID, J.P.; BAHIA, M.V.; AGUIAR, R.M. Métodos para determinação de atividade antioxidante in vitro em substratos orgânicos. Quim Nova. 2010, 33, 2202-2210.

[38] XIA, E.Q.; DENG, G.F.; GUO, Y.J.; LI, H.B. Biological activities of polyphenols from grapes. Int. J. Mol. Sci. 2010, 11, 622-646.

[39] PETRY, R.D.; REGINATO, F.; DE PARIS, F.; GOSMANN, G.; SALGUEIRO, J.B.; QUEVEDO, K.F.; OSTEGA, G.G; SCHENKEL, E.P. Comparative pharmacological study of hydroethanol extracts of Passiflora alata and Passiflora edulis leaves. Phytother. Res. 2001, 15, 162-164.

[40] PEREIRA, C.A.M.; YARIWAKE, J.H.; LANÇAS, F.M.; WAUTERS, J.N.; TITS, M.; ANGENOT, L. HPTLC densitometric determination of flavonoids from Passiflora alata, P. edulis, P. incarnata and P. caerulea and comparison with HPLC method. Phytochem. Anal. 2004, 15, 241-248.

[41] REGINATTO, F.H.; DE-PARIS, F.; PETRY, R.D.; QUEVEDO, J.; ORTEGA, G.G.; GOSMANN, G.; SCHENKEL, E.P. Evaluation of anxiolytic activity of spray dried powders of two South Brazilian Passifl ora species. Phytother. Res. 2006, 20, 348-351.

[42] WANG, S.Y.; LIN, H.S. Antioxidant activity in fruits and leaves of blackberry, raspberry, and strawberry varies with cultivar and developmental stage. J. Agri. Food Chem. 2000, 48, 140-146.

[43] MOYER, R.A.; HUMMER, K.E.; FINN, C.E.; FREI, B.; WROLSTAD, R.E. Anthocyanins, phenolics, and antioxidant capacity in diverse small fruits: Vaccinium, Rubus, and Ribes. J. Agri. Food Chem. 2002, 50, 519-525.

[44] KOCA, I.; KARADENIZ, B. Antioxidant properties of blackberry and blueberry fruits grown in the Black Sea Region of Turkey. Sci. Hort. 2009, 121, 447-450.

[45] SOUZA, V.H.; BARBOSA, A.P.O.; CARDOSO, G.C.; MARRETO, R.N.; BARRETO-FILHO, J.; ANTONIOLlI, A.R.; SANTOS, M.R.V. Avaliação do potencial antidiabético de cinco plantas medicinais em ratos. Lat. Ame. J. Pharma. 2009, 28, 609-612.

[46] PAULRAJ, J.A.; SUBHARAMANIAN, H.; SURIYAMOORTHY, P.; KANAKASABAPATHI, D. Phytochemical screening, GC-MS analysis and enzyme inhibitory activity of Passiflora foetida L. Indo. Ame. J. Pharm. Res. 2014, 4, 35263534. 
[47] REZK, A.; AL-HASHIMI, A.; JOHN, W.; SCHEPKER, H.; ULLRICH, M.S.; BRIX, K. Assessment of cytotoxicity exerted by leaf extracts from plants of the genus Rhododendron towards epidermal keratinocytes and intestine epithelial cells. BMC Complem. Alter. Med. 2015, 15, 364.

[48] DELMONDES, G.A. Avaliação da citotoxicidade e atividade leishmanicida e tripanocida de extratos de Passiflora cincinnata Mast L. Cad. Cult. Ciênc. 2014, 13, 31-38.

[49] PORCHEZHIAN, E.; ANSARI, S.H.; SHREEDHARAN, N.K.K. Antihyperglycemic activity of Euphrasia officinale leaves. Fitoterapia 2000, 71, 522526.

[50] UCHIDA-MARUKI, H.; INAGAKI, H.; ITU, R.; KURITA, I.; SAI M.; ITO, I. Piceatanol lowes the blood glucose level in diabetic mice. Biol. Pharma. Bull. 2015, 38, 629-635.

[51] REIMBERG, M.C.H.; COLOMBO, R.; YARIWAKE, J.H. Multivariate analysis of the effects of soil parameters and environmental factors on the flavonoid content of leaves of Passiflora incarnata L.; Passifloraceae. Braz. J. Pharmacogn. 2009, 19, 853-859.

[52] MBAEBIE, B.O.; EDEOGA, H.O; AFOLAYAN, A.J. Phytochemical analysis and antioxidants activities of aqueous stem bark extract of Schotia latifolia Jacq. Asian Pac.

J. Trop. Biom. 2012, 2, 118-124.

[53] KUMARAN, A.; KARUNAKARAN, R. J. In vitro antioxidant activities of methanol extracts of five Phyllanthus species from India. LWT - Food Sci Technol. 2007, 40, 344-352.

[54] LAPENNA, D.; CIOFANI, G.; PIERDOMENICO, S.D.; GIAMBERARDINO, M.A.; CUCCURULLO, F. Reaction conditions affecting the relationship between thiobarbituric acid reactivity and lipid peroxides in human plasma. Free Rad. Biol. Med. 2001, 31, 331-335.

[55] SILVA, E.G.; BEHR, G.A.; ZANOTTO-FILHO, A.; LORENZI, R.; PASQUALI, M.A.B.; RAVAZOLO, L.G.; BORDIGNON JR.; C.L.; SILVA, F.A.; ABOY, A.L.; BASSANI, V.L.; HENRIQUES, A.T.; REGINATTO, F.H.; DALPIZZOL, F.; MOREIRA, J.C.F. Antioxidants activities and free radical scavenging potential of Bauhinia microstachya (Raddi) MACBR (caesalpinaceae) extracts linked to their polyphenol content. Biol. Pharma. Bull. 2007, 30, 1488-1496.

[56] BUDNI, P.; PETRONILHO, F.C.; ZANETTE, V.C.; MARCONDES, C.; ZOCH, A.N.; REGINATTO, F.H.; DAL-PIZZOL, F. Estudos preliminares da atividade antioxidante do extrato hidroetanólico de folhas jovens e adultas de Tabebuia heptaphylla (Vell.) Toledo (ipê-roxo). Acta Farma. Bona. 2007, 26, 394-398.

[57] SOUZA, P.M.; SALES, P.M.; SIMEONI, L.A.; SILVA, E.C.; SILVEIRA, D.; MAGALHÃES, P.O. Inhibitory activity of $\alpha$-amylase and $\alpha$-glucosidase by plant extracts from the Brazilian cerrado. Planta Med. 2012, 78, 393-399.

[58] SLATER, T.F.; SAWYER, B.; STRAULI, U.D. Studies on succinate-tetrazolium reductase systems. III. points of coupling of four different tetrazolium salts. Biochim. Biophys. Acta. 1963, 77, 383. 
[59] MOSMANN T. Rapid colorimetric assay for cellular growth and survival: application to proliferation and cytotoxicity assays. J. Immunol. Methods. 1983, 65, 55-63.

[60] DENIZOT, F.; LANG, R. Rapid colorimetric assay for cell growth and survival. Modifications to the tetrazolium dye procedure giving improved sensitivity and reliability. J. Immunol Methods. 1986, 22, 271-277. 